\title{
Predictive Model for Measuring Sustainability of Manufacturing Companies
}

\author{
${ }^{1}$ Brno University of Technology \\ Kolejni 2906/4, 61200 Brno, Czech Republic \\ E-mail.kocmanova@fbm.vutbr.cz,docekalova@fbm.vutbr.cz \\ ${ }^{2}$ Mykolas Romeris University \\ Ateities st. 20, LT-08303 Vilnius, Lithuania \\ E-mail.zaneta.simanaviciene@ktu.lt \\ cross $^{\text {ref }}$ http://dx.doi.org/10.5755/j01.ee.26.4.11480
}

Alena Kocmanova1, ${ }^{1}$ aneta Simanaviciene ${ }^{2}$, Marie Pavlakova Docekalova1

\begin{abstract}
The article describes the construction of a predictive model of corporate sustainability, the DACSI Index, for measuring sustainability. The aim of the paper is to propose a predictive model DACSI Index based on economic IEcoi and non-financial indicators $I_{E S G i}$ and appropriately selected predictive models $D A_{E c o}$ and $D A_{E S G}$ for manufacturing companies according to CZ-NACE classification. Predictive models were developed with the use of Multiple Discriminant Analysis (MDA). MDA results showed that the inclusion of non-financial indicators did not result in any significant changes in the classification of companies into individual groups compared to classification on the basis of economic indicators only. From MDA results it also follows that the statistical significance of non-financial indicators is low, but they signal a causal relationship between individual economic and non-financial indicators of sustainability. The results also showed that the predictive model DACSI Index, composed of economic indicators, environmental indicators, social indicators and corporate governance indicators has a much higher accuracy than the predictive model composed of economic indicators only. The essential conclusion of our research into corporate sustainability measurement is that the traditional performance assessment using economic indicators no longer suffices and does not reflect current performance of the company from the long-term perspective, and it is therefore necessary to include both economic and non-financial indicators into the predictive model DACSI Index. And the predictive model DACSI Index is just the type of model that will provide relevant information about the company's sustainability status to both the owners and investors.
\end{abstract}

Keywords: Sustainability Measurement, Predictive Model, Multiple Discriminant Analysis, Indicators, Economics, Environmental, Social, Corporate Governance, Performance.

\section{Introduction}

Success of any company depends nowadays on the extent to which it capitalizes on its competitive advantage, and that is when sustainable development comes to the fore.

The concept of sustainable development encompasses a series of sub-activities and tasks that are being gradually implemented and achieved. This is an incremental system, which, at every moment of its existence, sets out from what has already been created (Soppe, 2009).

In the context of sustainable development, there is a need for economic as well as non-financial indicators that would be able to measure corporate sustainability. They are, in particular, multivariate models using such indicators that have a specific weight assigned to them. Comprehensive corporate performance is then expressed as a composite indicator that is able to measure corporate sustainability.

Composite indicators have also been developed at the level of business entities, particularly in the area of finance, to evaluate their financial standing, i.e. models of Financial standing, or models attempting to identify the risk of bankruptcy, i.e. bankruptcy models. Composite indicators designed to assess the financial stability of the company or assess the likelihood of bankruptcy of the company are presented as predictive models.
The aim of the paper is to present a construction of a predictive model $D A_{C S I}$ Index for measuring sustainability of companies from the manufacturing industry that supports decision-making of owners and investors. The methods section defines individual stages in the construction of the predictive model $D A_{C S I}$ Index, which is built on the methodological approach of the draft of the predictive model $D A_{E c o}$ utilizing economic indicators $I_{E c o i}$ and the predictive model $D A_{E S G}$ utilizing environmental, social and corporate governance indicators $I_{E S G i}$. The empirical analysis is based on descriptive statistics, univariate and multivariate analyses.

Predictive models $D A_{E c o}, D A_{E S G}$ and $D A_{C S I}$ were determined by methods Discriminant Multiple Analysis. The basis for the predictive model $D A_{C S I}$ Index is the determination of the economic, environmental, social and corporate governance indicators. Economic indicators can easily be obtained from financial statements, and these are defined by the choice from among the indicators of profitability, financial stability and productivity, and cash flow-based indicators. The environmental, social and corporate governance indicators include data that are both quantitative and qualitative in nature, and are derived from findings obtained in previous research conducted between 2011 and 2014, and from documents of international institutions such as GRI, CFA Institute, EFFAS, IFAC and ASSET4. The hypothesis tested attempts to find out whether 
the inclusion of non-financial indicators will cause changes in classification into groups ( 0 - sustainable, 1 - unsustainable) compared with classification based solely on economic indicators. The testing showed that there are no significant changes in the classification into groups ( 0 - unsustainable, 1 - sustainable) between the predictive model $D A_{C S I}$ Index, which includes non-financial indicators, and the predictive model $D A_{E c o}$. Although the inclusion of social and corporate governance indicators causes some reclassification, the groups are almost identical with the original groups formed with the use of economic indicators only. In empirical research, the predictive model $D A_{C S I}$ Index was compared with the predictive model $D A_{C S I I B}$, where the financial standing index $I B$ is used instead of index $D A_{E c o}$, the results are substantially identical.

The conclusions of empirical research indicate that the predictive model $D A_{C S I}$ Index for measuring the sustainability of companies through economic and nonfinancial indicators is necessary because measuring the performance of companies using financial indicators is nowadays insufficient. The predictive model $D A_{C S I}$ Index exhibits higher reliability than the predictive model $D A_{E c o}$. The predictive model $D A_{C S I}$ includes both economic indicators: $I_{E c o l} ; I_{E c o 2} ; I_{E c o 4} ; I_{E c o 6}$, non-financial indicators: $\left(I_{E n 1} ; \quad I_{E n 7} ; \quad I_{S o c 5} ; \quad I_{C g 2}\right.$ and environmental and social information $I_{C g 3}$. Thus constructed predictive model $D A_{C S I}$ Index evaluates companies on the basis of purposefully selected set of economic and non-financial indicators. The results of predictive model $D A_{C S I}$ Index can help owners, investors and managers assess whether the company is heading towards sustainability or unsustainability.

Predictive models based solely on financial indicators have been studied since 1930 to the present day by a number of foreign and domestic authors. The authors of the most famous predictive models include (Altman, 1968), who presented his linear discriminant model in 1968, (Ohlson, 1980), who introduced his logit model in 1980, and (Zmijewski, 1984), who developed probability of bankruptcy probit models. Pioneers in evaluating the financial health of Czech companies are Mr. and Mrs. Neumaier with their IN indices (Neumaier \& Neumairova, 2002, 2005). The models based on financial indicators suffer from many shortcomings, because of their reliance on historical data, their focus on only short-term goals, but the main problems are their apparent lack of connectedness to strategies, their frequent nontransparency and unreliability. To avoid those shortcomings, non-financial indicators come increasingly to the fore, which are included in the construction of predictive models, or predictions are based solely on examining these variables.

\section{The Conceptual Framework}

Predictive models are nowadays useful predictive tools. Authors of predictive models often use financial indicators as a starting point. Financial indicators are actually a measure of the company's success and reflect the company's performance. For that reason, most economists base their corporate predictive models on a financial analysis and strive to create a suitable setup of individual financial indicators that would unambiguously define the degree of the company's financial stability. The best known of the bankruptcy models used in practice are Beaver profile analysis, Altman models, Taffler model, Beerman Discriminant Function, Zmijewski's model and Ohlson's model.

The financial standing models include Kralicek Quick Test, Tamari's model, Index of Financial Standing (IB), Rudolf Doucha's set of balance analyses, IN indices, and others. Financial standing indicators reflect the quality of the company based on its performance, and are oriented to owners and investors. In their literature overview of predictive models, (Altman \& Narayanan, 2002) listed 43 works from 22 countries, and they specified the prediction method and the input data used, how the groups were defined and what results were achieved. Another literature review is included in the study by (Bellovary et al., 2007), and it gives a brief description of 165 corporate predictive models that were published between 1966 and 2005. According to (Declers et al., 1992), predictive model should include indicators based on gross added value, which increases model reliability. Values of such indicators, however, differ considerably between different sectors, which should be taken into account. In addition to financial ratios, (Becchetti \& Sierra, 2003) include indicators reflecting customer concentrations, the presence of competitors and technical efficiency in the model. (Xu \& Wang, 2009) complemented their model based on ratio indicators with technical efficiency calculated by means of data envelopment analysis (DEA).

Predictive models based only on financial indicators suffer from many shortcomings, and therefore also nonfinancial indicators attract more and more attention and are included in the construction of predictive models, or predictions are based solely on examining these variables. The most widespread and elaborate system of evaluation by means of financial and non-financial indicators is the Balanced Scorecard (BSC) developed by (Kaplan \& Norton, 2000). A number of other authors (Lau \& Sholihin, 2005; Fernandes et al., 2006; Prieto \& Revile, 2006; Wier et al., 2007; Cardinaels \& van Veen-Dirks, 2010; Fulop et al., 2014) also pursued the topic of comprehnsive assessment of corporate performance through a system of financial and non-financial indicators, but the practical application of these systems of indicators remains a problem because there is no uniform approach to identification, classification, measurement and evaluation by means of financial and nonfinancial indicators.

(Pollak, 2003) developed a well-known predictive model that uses both financial and non-financial indicators for corporate evaluation. (Argenti, 1976) constructed a nonfinancial predictive model suitable for internal analysis. His model was designed on the basis of non-financial indicators that diagnosed shortcomings and signs of corporate failings. The model is based on numerical scoring of individual factors, with the sum of points representing the final "score. (Ittner et al., 2003) examined in their study the relation between satisfaction measurement system, economic performance, and two general approaches to strategic performance measurement: greater measurement diversity and improved alignment with firm strategy and value drivers. They found that the results are associated with higher satisfaction and performance of the share markets. (Grunert et al., 2005) confirmed that the models that include both 
financial and non-financial indicators show higher reliability in predicting bankruptcy compared to models that are based solely on financial indicators. (Altman et al., 2010) studied models made up of both financial and non-financial indicators (related to the audit, the size and age of the company). They came to the conclusion that the addition of these non-financial indicators improved the reliability of the model by $13 \%$.

Recently, there has been a growing interest in the use of financial and non-financial indicators for the measurement of sustainable corporate performance. The issue of sustainability at the corporate level and its relation to performance is dealt with by a number of foreign and domestic authors (Kristensen \& Westlund, 2004; Rutkauskas et al., 2014). A number of concepts, tools and indicators has been developed that focus on measuring and reporting sustainability, but there is no such thing as a uniform approach to measuring sustainability.

\section{Research Methodology}

The authors dealt with the construction of a composite indicator for sustainability measurement, the Corporate Sustainability Index (CSI), in 2013 and 2014. They used the principal component analysis (PCA) to determine the CSI, and the OECD Composite Indicators Methodology (Nardo, 2005; OECD, 2008) to construct it. The principal component analysis procedure has a number of advantages but also disadvantages. The fundamental disadvantage of the PCA procedure is that weights are calculated on the data from each particular year. Composite indicators whose weights are annually recalculated cannot be compared.

The study of predictive models for company financial stability assessment offers itself as an appropriate approach to the design of corporate sustainability indicators comparable in time. Although predictive financial models are criticized for their inaccuracy by many authors, a majority of authors nevertheless agree that their accuracy is essentially sufficient (Lacher et al., 1995). (Balcaen \& Ooghe, 2007) reached a most interesting conclusion with respect to models when they compared selected models based on discriminant analysis and models based on logistic regression. They found that model accuracy is more affected by indicators included in the model than by the method by means of which the model was derived. (Wu et al., 2010) compared the original Altman model with models whose design was not based on discriminant analysis (e.g. Ohlson's logit model). The comparison showed that the Altman model is less reliable in comparison with other models. (Russ et al., 2009) see the major drawback of Altman's Z-score in its orientation to manufacturing companies.

The construction of the predictive model of corporate sustainability, the $D A_{C S I}$ Index - is based on empirical research divided into three stages. The first stage is devoted to the methodology for the classification of companies based on economic indicators $I_{E c o i}$ by selecting a suitable predictive model $D A_{E c o}$. The second phase deals with the methodology for the classification of companies based on the evaluation of non-financial indicators $I_{E S G i}$, which cover the areas of environmental, social and corporate governance indicators for the predictive model $D A_{E S G}$. The third phase is devoted to the methodology for comprehensive classification of companies based on economic ( $\left.I_{E c o i}\right)$ and non-economic $\left(I_{E S G i}\right)$ indicators for the construction of the $D A_{C S I}$ Index, i.e. the predictive model.

An analysis of Czech companies showed that financial stability is predominantly assessed on the basis of predictive models, i.e. models developed by (Neumaier \& Neumaierova, 2002, 2005). These models were developed using the Multiple Discriminant Analysis (MDA).

The material for empirical research into non-financial indicators for corporate sustainability measurement came from findings from previous research in the years 2011-2014 (Kocmanova, 2014), when environmental, social and corporate governance performance indicators were determined on the basis of theoretical knowledge gained from documents and guidelines of international institutions. The most important institution dealing with sustainability and indicators is the Global Reporting Initiative (GRI), which has set up a reporting framework and a set of environmental, social and economic indicators (GRI, 2013). Another institution is the CFA Institute, which has created a manual for investors (Schacht et al., 2009). The European Federation of Financial Analysts Societies (EFFAS) has set up ESG performance indicators for industries, and is currently considering ways of integrating ESG indicators into investment decisions. The International Federation of Accountants (IFAC) has prepared an overview of performance metrics and KPIs for ESG performance indicators.

\section{Results and Discussion}

Empirical research is aimed at companies from the manufacturing industry according to CZ-NACE classification with over 250 employees. The analyzed period was 2008 2012. The analyzed of 88 companies from the manufacturing industry according to CZ-NACE classification Manufacture: 10 - of food products, 11- of beverages, 13 - of textiles, 20 - of chemicals and chemical products, 22 - of rubber and plastic products, 24 - of basic metals, metallurgical processing of metals, 25 - of fabricated metal products, except machinery and equipment, 26 - of computer, electronic and optical equipment, 27 - of electrical equipment and 28 - of machinery and equipment. The construction of the predictive model of corporate sustainability, the $D A_{C S I}$ Index is based on the determination of the predictive model $D A_{E c o}$ from economic indicators $I_{E c o i}$, and the predictive model $D A_{E S G}$ from nonfinancial indicators $I_{E S G i}$.

For the construction of predictive models $D A_{E c o}, D A_{E S G}$ and $D A_{C S I}$ Index, the Multiple Discriminant Analysis was used. The general equation of discriminant:

$$
Y=a_{1} X_{l}+a_{2} X_{2}+\ldots \ldots \ldots \ldots+a_{p} X_{p}
$$

where $a_{1}, \ldots a_{p}$ are coefficients of discrimination and $\mathrm{X}_{1}, \ldots \mathrm{X}_{\mathrm{p}}$ are selected independent variables that best explain the division into groups.

Discriminant analysis undertakes to calculate the value of the discriminant function, on the basis of which entities are assigned to the primary class (Anderson, 2007). The SPSS 22.0 software was used for the MDA application.

The first step in the analysis is to decide what criterion will be taken as an explained variable, or, rather, how individual groups will be defined. For a definition of groups 
in the case of companies, the criterion are prospering companies, i.e. companies that made profit in three consecutive years, and their return on equity in the last year was higher than $8 \%$ (this indicator is crucially important for the owners of the company because it measures the profitability of invested capital), and others are considered failing companies.

Appropriate explaining variables that affect the value of the explained variable must then be selected. Economic indicators $I_{E c o i}$ for the predictive model $D A_{E c o}$ are ratios selected from a broad group of indicators used in predictive models. They are divided into groups, i.e. into profitability ratios, financial stability indicators, productivity indicators and a cash flow-based indicator. In the construction of the predictive model for measuring corporate sustainability, the eleven $\mathrm{I}_{\mathrm{Ecoi}}$ ratios can be replaced with the Index of Financial Standing (IB), or some other models, IN indeces, etc. in Table 1.

Economic Indicators and Index of Financial Standing

Table 1

Index of financial standing (IB) (German model)

\begin{tabular}{|c|c|c|}
\hline IEcoi - Economic indicators & \multicolumn{2}{|c|}{ Index of financial standing (IB) (German model) } \\
\hline IEco1- EAT / SF (ROE) & \multicolumn{2}{|l|}{$+1,5 * \mathrm{CF} / \mathrm{L}$} \\
\hline IEco2 - EBIT / A (ROA) & \multicolumn{2}{|l|}{$+0,08 * \mathrm{~A} / \mathrm{L}$} \\
\hline IEco3 - EAT + IP / NCL + SF & \multicolumn{2}{|l|}{$+10 * \mathrm{EBT} / \mathrm{A}$} \\
\hline IEco4 - EBIT / S (ROS) & \multicolumn{2}{|l|}{$+5 * \mathrm{EBT} / \mathrm{T}$} \\
\hline IEco5 - SF + NCL / A & \multicolumn{2}{|l|}{$+0,3 * \mathrm{St} / \mathrm{T}$} \\
\hline IEco6 - CF / A & \multicolumn{2}{|l|}{$+0,1 * \mathrm{~T} / \mathrm{A}$} \\
\hline IEco7 - VA / OR & \multirow{6}{*}{$\begin{array}{l}\text { Prospering companies } \\
\mathrm{IB} \geq 3 \\
\text { extremely good economic situation } \\
2 \leq \mathrm{IB}<3 \\
\text { very good economic situation } \\
1 \leq \mathrm{IB}<2 \\
\text { good economic situation } \\
0 \leq \mathrm{IB}<1 \\
\text { problematic economic situation }\end{array}$} & \multirow{6}{*}{$\begin{array}{l}\text { Failing companies } \\
-1 \leq \mathrm{IB}<0 \\
\text { poor economic situation } \\
-2 \leq \mathrm{IB}-1 \\
\text { very poor economic situation } \\
\mathrm{IB}<-2 \\
\text { extremely poor economic situation }\end{array}$} \\
\hline IEco8 - OR / A & & \\
\hline IEco9 - L / SF & & \\
\hline IEco10 - A / L & & \\
\hline IEco11 - VA / CE & & \\
\hline & & \\
\hline
\end{tabular}

Methodical approach in the first stage of calculating the predictive model $D A_{E c o}$. The predictive model is comprised of 11 economic indicators $I_{E c o i}$. Indicators that exhibit collinearity have been discarded. To increase the statistical significance (discriminating power) of economic indicators, an analysis of outliers, data normality and correlations between indicators was performed. In the case of nonnormality, indicators are transformed. In the next step, MDA is applied to economic indicators $I_{E c o 3}, I_{E c o 5}, I_{E c o}$, $I_{E c o 8}$, $I_{E c o 9}, I_{E c o l 0}, I_{E c o l l}$, which are gradually eliminated and the model are recalculated after individual indicators have been removed. Wilks' Lambda indicates the significance of the discriminant function, the model explains $50,1 \%$ of the variability, it is the inverse to canonical correlation. The discriminant function suitable for differentiating between groups of companies:

$$
\begin{aligned}
& \text { DAEco }=-1,761+11,628 \text { IEco6 }-0,007 \text { IEco } 2+ \\
& 0,048 \text { IEco4 + 0,030IEco } 1
\end{aligned}
$$

and explains $88,4 \%$ differences between companies in the two defined groups.

$D A_{E c o}$ values less than -1.153 rank the company among Group 0 (failing) companies, $D A_{E c o}$ values greater than 0.830 rank the company among Group 1 (prospering) companies. $D A_{E c o}$ from the interval $\left.<-1,153 ; 0,830\right\rangle$ do not give unambiguous information on which group the company belongs to. Economic indicators that enter the predictive model $D A_{E c o}: I_{E c o l}-\mathrm{EAT} / \mathrm{SF}=\mathrm{ROE} ; I_{E c o 2}-\mathrm{EBIT} / \mathrm{A}=$ $\mathrm{ROA} ; I_{E c o 4}-\mathrm{EBIT} / \mathrm{S}=\mathrm{ROS} ; I_{E c o 6}-\mathrm{CF} / \mathrm{A}$ in (Figure 1) and (Figure 2).

The primary classification reveals a moderately "skewed" division into groups, with Group 1 companies being more numerous. It is clear that high values of the variable IEco6 - CF / A, which, based on the analysis performed helps best to explain the division into groups, move observations closer to Group 1 . The decisive indicator IEco6 is the most influential and measures how much profit a company can make for ever unit of total assets (invested capital). Other important variables are profit ratio / profitability. These indicators are designed to reflect the company's ability to utilize its assets or sales, to make profit. It can be expected that the assignment of a company to the group of "prospering companies" will be positively dependent on each of the indicators included in this group. The extent to which they all together contribute to the division into groups can only be verified by a multivariate analysis.

The direction of the effect of other variables, $I_{E c o 4}$ - EBIT / S, pushes companies towards Group 1. This indicator measures the profitability (effect) of sales and allows us to estimate how effectively a company operates, how it controls its costs and what position the company has on the market from the success of its products' point of view. A negative value of the indicator $I_{E c o 2}$ - EBIT / A moves companies closer to Group 0 . This indicator should be considered a basic measure of the profitability of the total resources invested in the business, and thus it reflects the overall efficiency of the company, its overall earnings power. The extreme value of this indicator is based on the requirement for a positive effect of financial leverage. 


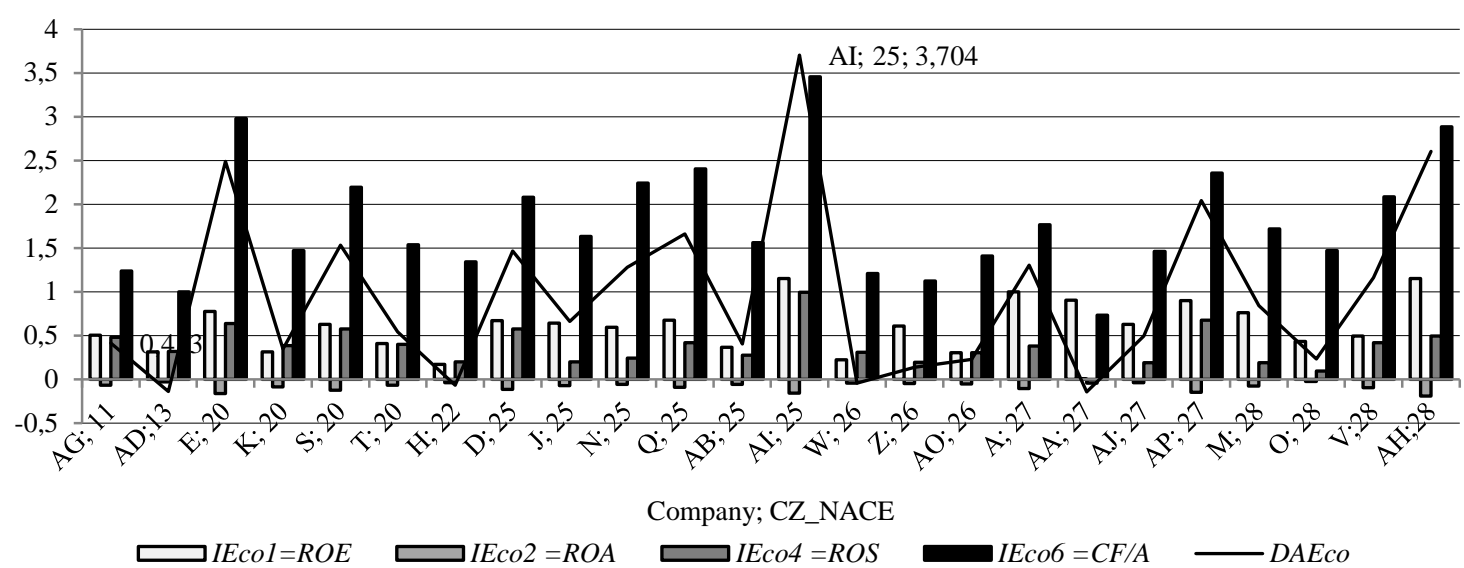

Figure 1. Prospering Companies According to Discriminant Analysis DAEco

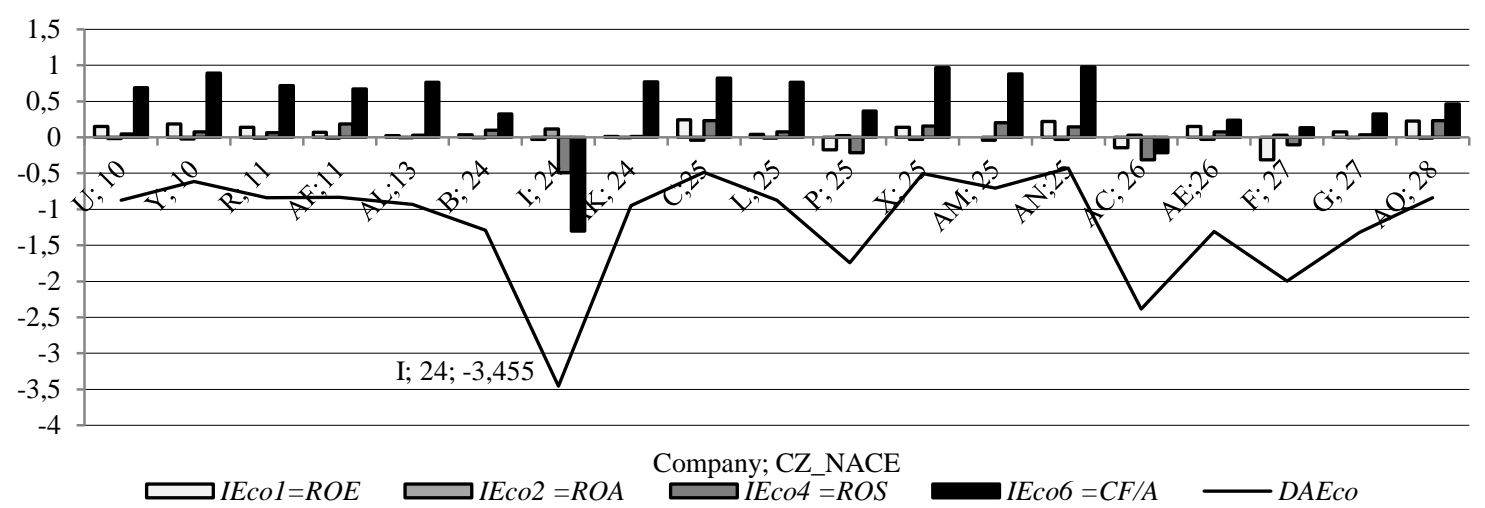

Figure 2. Failing Companies According to Discriminant Analysis $D A_{E c o}$

$I_{E c o l}$ - EAT / SF: this indicator assesses the return on the investment the owners made in the company. The indicator is crucial for company owners because it measures the profitability of the invested capital. For creditors, this indicator has a supportive role. The extent to which a company increases the value of its equity provides information also about the possible extent of external capital appreciation. The extreme value is similar as in the previous indicator. In the second stage, the predictive model $D A_{E S G}$, was determined from environmental, social and corporate governance indicators $I_{E S G i}$; these are used in the construction of the $D A_{C S I}$ Index measuring corporate sustainability. To calculate the predictive model $D A_{E S G}, 17 I_{E S G i}$, indicators were used: seven environmental indicators $I_{\text {Envi }}$, six social indicators $I_{S o c i}$ and four corporate governance indicators $I_{C g i}$ (Table 2). The use of MDA requires that groups are defined and companies divided into effective and ineffective, which is accomplished by Data Envelopment Analysis. Transformation is applied on individual $I_{E S G i}$ indicators with the aim to change their distribution so that it gets closer to normality. Transformed of the indicators $I_{E n 1}, I_{E n 2}, I_{E n 3}, I_{E n 4}$, $I_{E n 5,} I_{S o c 1}, I_{S o c 2,} I_{S o c 3}, I_{S o c 6}, I_{C g 2}, I_{C g 3}, I_{C g 4}$ were gradually removed and the model recalculated after each indicator removal.

Table 2

Non-financial Environmental, Social and Corporate Governance Indicatos $I_{E S G}$

\begin{tabular}{|c|c|c|}
\hline Environmental group $(j=$ Envi $)$ & Social group $(j=$ Soc $)$ & Corporate governance group $(j=C g)$ \\
\hline $\mathbf{I}_{\text {Eni }}$ - Environmental indicators & $\mathbf{I}_{\text {Soci }}$ - Social indicators & $\mathbf{I}_{\mathrm{Cgi}}$ - Corporate governance indicators \\
\hline $\begin{array}{l}I_{E n I^{-}} \text {Non-investment expenditures for the } \\
\text { protection of the Environment /Added value [\%] }\end{array}$ & $\begin{array}{l}I_{S o c l^{-}} \text {Monetary support of local community } \\
\text { and gifts to municipalities / Added value [\%] }\end{array}$ & $\begin{array}{l}I_{C g 1}-\text { Collective agreement } \\
{[\text { yes }=0,52 ; \text { no }=0,48]}\end{array}$ \\
\hline$I_{E n 2}$-Total emissions to air / Added value [t/EUR] & $\begin{array}{l}I_{S o c 2^{-}} \text {Number of women / Average number of } \\
\text { employees [\%] }\end{array}$ & $\begin{array}{l}I_{C g^{2}}-\text { Reports from environmental and social } \\
\text { areas }[\text { yes }=0,64 ; \text { no }=0,36]\end{array}$ \\
\hline $\begin{array}{l}I_{E n 3}-\text { Total greenhouse gas emissions / Added } \\
\text { value }[\mathrm{t} / \mathrm{EUR}]\end{array}$ & $\begin{array}{l}I_{S o c 3^{-}} \text {Number of terminated employments / } \\
\text { Average number of employees [\%] }\end{array}$ & $\begin{array}{l}I_{C g 3}-\text { Code of ethics } \\
{[\text { yes }=0,72 ; \text { no }=0,28]}\end{array}$ \\
\hline $\begin{array}{l}I_{E n 4^{-}} \text {Total consumption of renewable energy } \\
\text { /Added value }[\mathrm{GJ} / \mathrm{EUR}]\end{array}$ & $\begin{array}{l}I_{S o c 4}-\text { Wage costs / Average number of } \\
\text { employees[EUR/Number] }\end{array}$ & $\begin{array}{l}I_{C g 4} \text {-Total financial value of remunerations to } \\
\text { Board of Directors and Supervisory Board / } \\
\text { Added value [\%] }\end{array}$ \\
\hline $\begin{array}{l}I_{E n 5^{-}} \text {Total annual consumption of water } \\
\text { / Added value }\left[\mathrm{m}^{3} / \text { year/EUR] }\right.\end{array}$ & $I_{S o c 5}$-Wage costs / Added value [\%] & \\
\hline $\begin{array}{l}I_{E n \sigma^{-}} \text {Total annual production of waste / Added } \\
\text { value [t/EUR] }\end{array}$ & $\begin{array}{l}I_{S o c 6}-\text { Education and training expenditures / } \\
\text { Added value [\%] }\end{array}$ & \\
\hline $\begin{array}{l}I_{E n 7} \text { Total annual production of hazardous waste / } \\
\text { Added value [t/EUR] }\end{array}$ & & \\
\hline
\end{tabular}

Source: Kocmanova et al., 2014 
The discriminant function suitable for discriminating groups of companies:

$$
\begin{aligned}
& D A_{E S G}=-5,728+0,490 I_{E n 6}+0,250 I_{E n 7}+ \\
& 4,419 I_{S o c 4}+1,297 I_{S o c 5}+26,319 I_{C g 2}
\end{aligned}
$$

and explains $65,9 \%$ of differences between companies in the two defined groups. $D A_{E S G}$ values less than -0.426 identify companies that belong to Group 0 (ineffective companies), $D A_{E S G}$ values greater than 0,465 point to a similarity with Group 1 companies (effective companies). $D A_{E S G}$ values from the interval $\left.<-0,426 ; 0,465\right\rangle$ do not give unambiguous information on which group the company belongs to.

For MDA purposes, non-financial environmental, social and corporate governance indicators are divided into indicators $\mathrm{Iji}^{+}$, whose increasing value has a positive impact on corporate sustainability, and indicators Iji -, whose increasing value has a negative impact on corporate sustainability.

The resulting positive / negative impact of indicators on corporate sustainability for the prediction model $D A_{E S G}: I$ ${ }_{\text {En6 }} ; I^{-}{ }_{\text {En }} ; I^{+}{ }_{S o c 4} ; I^{+}{ }_{S o c 5} ; I^{+}{ }_{C g 2}$ (Figure 2) and (Figure 3).

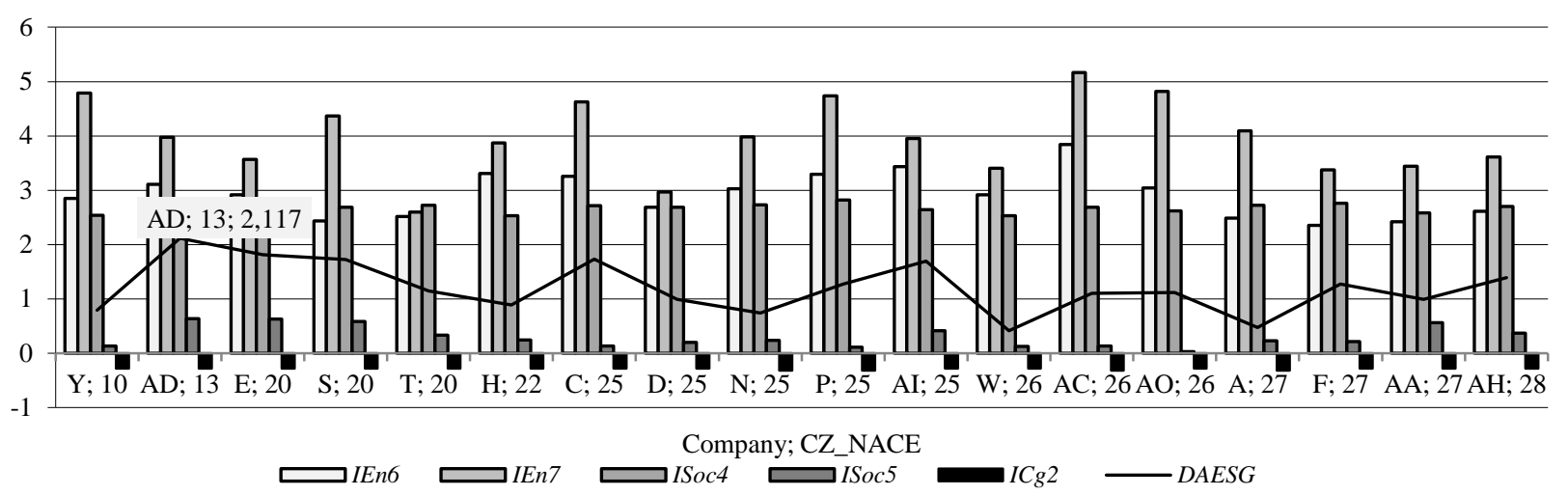

Figure 3. Effective Companies According to Discriminant Analysis DAESG

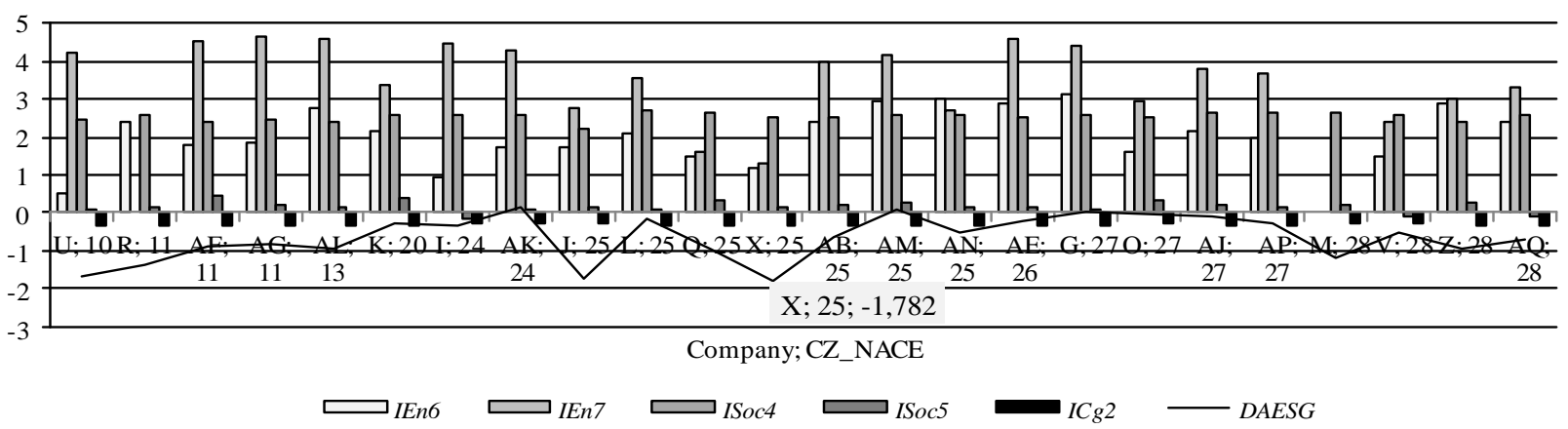

Figure 4. Ineffective Companies According to Discriminant Analysis DAESG

For a classification of companies into effective and ineffective, the decisive environmental indicators for industrial companies are: $I^{-}{ }_{E n 6}$ and $I_{E n 7}^{-}$. Social indicators $I$ ${ }^{+}{ }_{S o c 4}$, i.e. payroll productivity, and $I{ }^{+}{ }_{S o c 5}$, i.e. labour productivity are also important for industrial companies. The indicator $I^{+}{ }_{\mathrm{Cg} 2}$, i.e. corporate governance transparency towards employees, does not manifest itself as a decisive factor. It is very interesting to note that social indicators such as $I_{S o c 1}, I_{S o c 2}, I_{S o c 3}$ and $I_{S o c 6}$ do not have a significant effect on the overall evaluation of companies.

Methodological procedure in the third stage is based on the use of MDA and on testing the hypothesis whether selected non-financial indicators of the prediction model $D A_{E S G}$ can "explain" the classification into groups ( 0 or 1$)$ on the basis of financial variables.

HYPOTHESIS: Classification based on economic and non-financial indicators must result in the same (almost the same) classification as the previous one based on economic indicators only.

MDA is again comprised of economic indicators from $D A_{E c o}$, i.e. $I_{E c o l} ; I_{E c o 2} ; I_{E c o 4} ; I_{E c o 6}$, to which $D A_{E S G}$ non-financial indicators, i.e. $I_{E n i} I_{S o c i}$ and $I_{C g i}$, were added gradually. Using MDA, transformed of the indicators $I_{E n 2}, I_{E n 3}, I_{E n 4}, I_{E n 5}, I_{E n 6}, I_{S o c l}$, $I_{S o c 2,} I_{S o c 3}, I_{S o c 4}, I_{S o c 6}, I_{C g l}, I_{C g 4} I_{C g 5}$ were gradually removed and the model recalculated after individual indicators were removed.

The model explains $75,5 \%$ variability, it is the inverse to canonical correlation. The discriminant function suitable for discriminating between groups of companies:

$$
\begin{aligned}
& D A_{C S I}=-0,045+14,483 I_{E c o 6}-0,011 I_{E c o 2}+0,048 I_{E c o 4}+ \\
& 0,031 I_{E c o l}+3,138 I_{C g 3}-0,095 I_{E n 7}+1,058 I_{C g 2}-0,011 I_{E n 1} \\
& -2,304 I_{S o c 5}
\end{aligned}
$$

and explains $97,6 \%$ of differences between companies in the two defined groups.

$D A_{C S I}$ values under -1,435 signal that the company belongs to Group 0 (companies not heading towards sustainability), while $D A_{C S I}$ values greater than 1,076 point to a similarity with companies in Group 1 (companies heading towards sustainability). $D A_{C S I}$ values from the interval <-1,435; $1,076>$ do not give unambiguous information about the company's sustainability status (Table 3 ). 
Table 3

Predictive Models $D A_{E c o}, D A_{C S I B}$ and $D A_{C S I}$ Index for Manufacturing Companies According to CZ-NACE Classification

\begin{tabular}{|c|c|c|c|c|c|c|c|c|c|c|c|c|c|c|c|}
\hline Company & $\begin{array}{c}\mathrm{CZ}_{-} \\
\mathrm{NACE}\end{array}$ & Group & $D A_{E c o}$ & Group & $\boldsymbol{D A}_{C S I B}$ & Group & $D A_{C S I}$ & Company & $\begin{array}{c}\mathrm{CZ}_{-} \\
\mathrm{NACE}\end{array}$ & Group & $D \boldsymbol{A}_{E c o}$ & Group & $\boldsymbol{D A}_{C S I I B}$ & Group & $D A_{C S I}$ \\
\hline $\mathrm{AI}$ & 25 & 1 & 3.690 & 1 & 2.881 & 1 & 3.920 & $\mathrm{AG}$ & 11 & 1 & 0.396 & 0 & -0.532 & 1 & \begin{tabular}{|l}
-0.290 \\
\end{tabular} \\
\hline $\mathrm{AH}$ & 28 & 1 & 2.590 & 1 & 2.784 & 1 & 2.795 & $\mathrm{C}$ & 25 & 0 & -0.503 & 1 & 0.071 & 1 & \begin{tabular}{|l}
-0.297 \\
\end{tabular} \\
\hline V & 28 & 1 & 1.145 & 1 & 2.878 & 1 & 2.363 & $\mathrm{Y}$ & 10 & 0 & -0.635 & 0 & -0.623 & 0 & \begin{tabular}{|l}
-0.406 \\
\end{tabular} \\
\hline $\mathrm{E}$ & 20 & 1 & 2.479 & 1 & 3.024 & 1 & 2.112 & $\mathrm{O}$ & 28 & 1 & 0.214 & 0 & -0.590 & 0 & \begin{tabular}{|l|}
-0.407 \\
\end{tabular} \\
\hline $\mathrm{Q}$ & 25 & 1 & 1.645 & 1 & 1.636 & 1 & 2.011 & $\mathrm{~L}$ & 25 & 0 & -0.894 & 1 & -0.293 & 0 & \begin{tabular}{|l|}
-0.461 \\
\end{tabular} \\
\hline $\mathrm{D}$ & 25 & 1 & 1.454 & 1 & 2.189 & 1 & 1.950 & $\mathrm{AK}$ & 24 & 0 & -0.972 & 0 & -0.519 & 0 & -0.614 \\
\hline $\mathrm{AP}$ & 27 & 1 & 2.028 & 1 & 1.935 & 1 & \begin{tabular}{|l|}
1.738 \\
\end{tabular} & $\mathrm{AL}$ & 13 & 0 & -0.948 & 0 & -0.708 & 0 & -0.784 \\
\hline $\mathrm{M}$ & 28 & 1 & 0.825 & 1 & 1.172 & 1 & 1.580 & AN & 25 & 0 & -0.446 & 0 & -0.900 & 0 & -0.791 \\
\hline $\mathrm{A}$ & 27 & 1 & 1.287 & 1 & 0.990 & 1 & 1.502 & AA & 27 & 1 & -0.168 & 0 & -1.615 & 0 & -0.812 \\
\hline $\mathrm{J}$ & 25 & 1 & 0.641 & 1 & 0.819 & 1 & 1.244 & AQ & 28 & 0 & -0.859 & 0 & -0.984 & 0 & -0.886 \\
\hline S & 20 & 1 & 1.520 & 1 & 1.382 & 1 & 1.043 & $\mathrm{AD}$ & 13 & 1 & -0.159 & 0 & -1.112 & 0 & -0.959 \\
\hline $\mathrm{N}$ & 25 & 1 & 1.261 & 0 & -0.500 & 1 & 0.832 & G & 27 & 0 & -1.342 & 0 & -1.003 & 0 & -1.011 \\
\hline $\mathrm{AO}$ & 26 & 1 & 0.210 & 1 & 0.487 & 1 & 0.785 & $\mathrm{R}$ & 11 & 0 & -0.858 & 0 & -0.810 & 0 & -1.065 \\
\hline AJ & 27 & 1 & 0.476 & 1 & -0.108 & 1 & 0.784 & $\mathrm{U}$ & 10 & 0 & -0.893 & 0 & -1.240 & 0 & \begin{tabular}{|l|}
-1.449 \\
\end{tabular} \\
\hline $\mathrm{AB}$ & 25 & 1 & 0.388 & 1 & 0.394 & 1 & 0.687 & AM & 25 & 0 & -0.720 & 0 & -1.732 & 0 & -1.603 \\
\hline $\mathrm{T}$ & 20 & 1 & 0.524 & 1 & 0.613 & 1 & 0.656 & $\mathrm{~F}$ & 27 & 0 & -2.018 & 0 & -1.715 & 0 & -1.988 \\
\hline W & 26 & 1 & -0.059 & 1 & 0.948 & 1 & 0.394 & $\mathrm{AE}$ & 26 & 0 & -1.327 & 0 & -1.431 & 0 & -2.115 \\
\hline $\mathrm{Z}$ & 26 & 1 & 0.117 & 1 & -0.235 & 1 & 0.239 & $\mathrm{AF}$ & 11 & 0 & -0.855 & 0 & -2.096 & 0 & -2.218 \\
\hline K & 20 & 1 & 0.331 & 1 & 1.642 & 1 & 0.107 & $\mathrm{P}$ & 25 & 0 & -1.764 & 0 & -2.536 & 0 & -2.383 \\
\hline $\mathrm{H}$ & 22 & 1 & -0.083 & 1 & 0.487 & 1 & 0.079 & I & 24 & 0 & -3.484 & 0 & -3.202 & 0 & -2.998 \\
\hline $\mathrm{X}$ & 25 & 0 & -0.522 & 1 & 0.546 & 1 & -0.004 & $\mathrm{AC}$ & 26 & 0 & -2.406 & 0 & -2.393 & 0 & -3.280 \\
\hline
\end{tabular}

The predictive model DACSI Index encompasses economic indicators, i.e. $I_{E c o l}$ - EAT / SF; $I_{E c o 2}$ - EBIT / A; $I_{E c o 4}-\mathrm{EBIT} / \mathrm{S} ; I_{E c o 6}-\mathrm{CF} / \mathrm{A}$, as well as non-financial indicators, i.e. $I_{E n I^{-}}$cost of environmental investments / added value; $I_{E n 7}$ - total annual production of hazardous waste / added value; $I_{S o c 5}$ - added value / payroll expenses; $I_{C g 2}$-environmental and social information; $I_{C g 3}$ - code of ethics. The testing of the hypothesis demonstrated that the inclusion of non-financial indicators did not result in any significant changes in the overall evaluation. Although some adjustments in classification occurred after social and corporate governance indicators were included, the groups formed were nevertheless still comparable with the original groups created from only economic indicators. To some extent, this result was expected. The spider charts below show predictive models $D A_{E c o}$ and $D A_{C S I}$ Index (Figure 5) and predictive models $D A_{C S I I B}$ and $D A_{C S I}$ Index (Figure 6). It is also possible to replace $I B$ with some other indices of financial standing, e.g. indices models IN, Z-Score, EVA, etc.

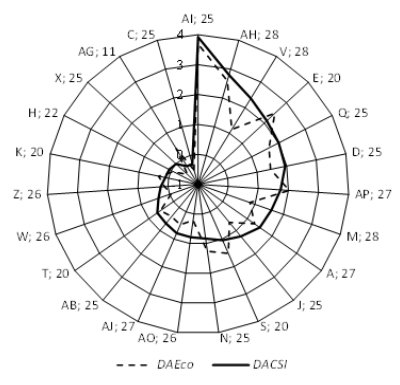

a)

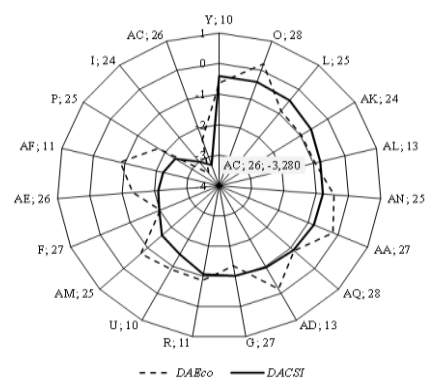

b)

Figure 5. Predictive models $D A_{E c o}$ and $D A_{C S I}$ Index for manufacturing companies according to CZ-NACE classification a) companies heading towards sustainability (Group 1); b) companies not heading towards sustainability (Group 0 )

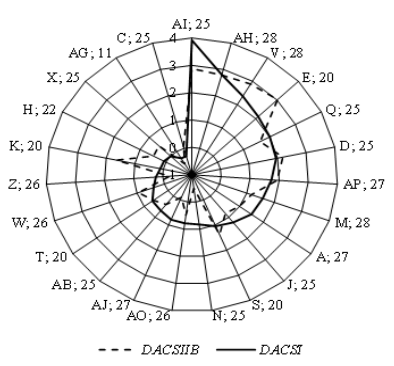

a)

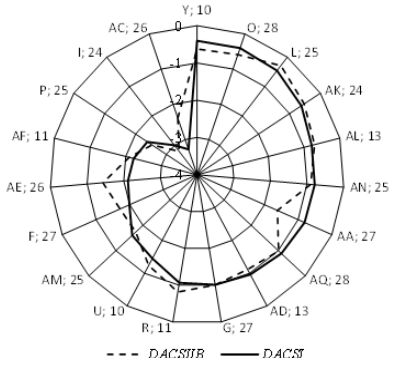

b)

Figure 6. $D A_{C S I I B}$ and $D A_{C S I}$ Index for manufacturing companies according to CZ-NACE classification a) companies heading towards sustainability (Group 1); b) companies not heading towards sustainability (Group 0) 
It follows from MDA results that the statistical significance of the effect of non-financial indicators is relatively small, except for those that indirectly characterize the company's economic efficiency. They are the social indicator, which characterizes the company's financial situation in terms of its employees, i.e. labour productivity added value / payroll expenses, and the code of ethics, an index that also affects employees. Environmental indicators attest to their relationship with economic indicators, the main one is the indicator 'cost of environmental investments / added value'. Basically, non-financial indicators are insignificant in terms of statistical tests, and their inclusion does not alter significantly the company's classification performed solely on the basis of economic indicators. This can be due to small informative power of the indicators used.

More interesting results could be obtained if the evaluation included more observations. Evaluation of selected indicators represents the most complicated and problematic part of the entire comprehensive evaluation design. Financial indicators can easily be objectively evaluated on the basis of financial statements. Nonmonetary indicators include data of both quantitative and qualitative nature, whose inclusion into the overall evaluation will help fulfil one of the basic objectives, i.e. the construction of a uniform system for the evaluation of corporate sustainability measurement (i.e. of the financial health and credibility of industrial companies). It follows from the results of the empirical research that the predictive model DACSI Index for measuring the sustainability of companies through financial and non- financial indicators is indispensable because the traditional financial analysis of companies focusing solely on economic indicators is now obsolete. Other significant conclusions regarding the inclusion of non-financial indicators in forecasting models are corroborated by research results reported by (Cardinaels \& van Veen-Dirks, 2010; Bhiman et al., 2010) The conclusion that an inclusion of non-financial indicators into the predictive model improves model reliability has also been reported by (Altman, Sabato \&Wilson, 2010).

\section{Conclusions}

The article describes the construction of the predictive model $D A_{C S I}$ Index for companies in the manufacturing sector as defined by CZ-NACE classification. A literature review revealed that attention is paid to both financial and nonfinancial indicators that can simultaneously integrate economic, ownership, organizational, social and environmental aspects. The importance of the predictive model lies in its ability to indicate whether a company is moving towards sustainability. The predictive model may influence decisions affecting the company's long-term strategy and can demonstrate the company's approach to comprehensive performance evaluation as well as integrated sustainability reporting.

The predictive model DACSI Index represents a composite indicator that has been constructed using the Multiple Discriminant Analysis.

Corporate evaluations that focus only on financial aspects are very one-sided and are now obsolete, and corporate evaluations are therefore being extended to also include other approaches. The basis of the predictive model DACSI Index is the determination of financial and nonfinancial indicators. First, economic indicators were determined from the group classification into profitability indicators, indicators of financial stability, productivity indicators and indicators based on cash flows. For the predictive model $D A_{E c o}$, four economic indicators which entered into the model $D A_{C S I}$ Index were selected by means of MDA. To compare the reliability of the model $D A_{C S I}$, results were compared with the use of the IB index of financial standing. The graphical representation using spider charts shows that the results of the model $D A_{C S I}$ in both versions are almost identical, even in terms of the division of companies into groups.

The predictive model DACSI Index can facilitate decision making of owners, potential investors, managers, and can also be useful as the initial composite indicator for integrated reporting. The purpose of the predictive model is to provide a simplified and quantified expression for a more complex composition of several indicators, and also to explain why companies with good economic results may not be sustainable.

The predictive model $D A_{C S I}$ Index offers the possibility to easily compare the performance of one company with other companies in the group. Above all, it is one of the ways of constructing a necessary tool for measuring corporate sustainability that will make it possible to evaluate the company's commitment to the principles of sustainability.

\section{Acknowledgement}

This paper is supported by the grant No. 14-23079S Measuring Corporate Sustainability in Selected Sectors of The Czech Science Foundation.

\section{References}

Altman, E. I. (1968). Financial Ratios, Discriminant Analysis and the Prediction of Corporate Bankruptcy. The Journal of Finance, 23(4), 589-609. http://dx.doi.org/10.1111/j.1540-6261.1968.tb00843.x

Altman, E. I., Haldeman, R. G., \& Narayanan, P. (1977). ZETA analysis: A new model to identify bankruptcy risk of corporations. Journal of Banking and Finance, 1(1), 29-51. http://dx.doi.org/10.1016/0378-4266(77)90017-6

Altman, E. I., Sabato, G., \& Wilson, N. (2010). The value of non-financial information in small and medium-sized enterprise risk management. The Journal of Credit Risk, 6(2), 1-33.

Anderson, R. (2007). The Credit Scoring Toolkit: Theory and Practise for Retail Credit Risk Management and Decision Automation. Oxford University Press Inc., New York.

Argenti, J. (1976). Corporate collapse: the causes and symptoms. London, Mc Graw-Hill. 
Balcaen, S., \& H. Ooghe (2006). 35 years of studies on business failure: an overview of the classic statistical methodologies and their related problems. The British Accounting Review. 38. 63-93. http//:dx.doi:10.1016/j.bar.2005.09.001

Becchetti, L., \& Sierra, J. (2003). Bankruptcy Risk and Productive Efficiency in Manufacturing Firms. Journal of Banking and Finance, 27, 2099-2120. http://dx. doi:10.1016/S0378-4266(02)00319-9

Bellovary, J., Giacomino, D., \& Akers, M. (2007). A review of bankruptcy prediction studies: 1930 to present. Journal of Education Finance, 33. 1-42.

Cardinaels, E., \& van Veen-Dirks P. M. G. (2010). Financial versus non-financial information: The impact of information organization and presentation in a Balanced Scorecard. Accounting, Organizations and Society, 35, 565-578. http://dx.doi.org/10.1016/j. aos.2010.05.003

Declers, M., Heins, B., \& Van Wymeersch, C. (1992). The use of value added rations in statistical failure prediction models:some evidence on Belgian annual accounts. Brussels Economic Review, 135, 353-378.

Fernandes, K. J., Raja V., \& Whalley A. (2006). Lessons from implementing the balanced scorecard in a small and medium size manufacturing organization. Technovation, 26(5), 623-634. http://dx. doi:10.1016/j.technovation. 2005.03.006

Fulop, G., Hernadi, B., Jalali, M., Meidute-Kavaliauskiene, I., \& Ferreira, F. (2014). Developing of Sustainability Balanced Scorecard for the Chemical Industry: Preliminary Evidence from a Case Analysis. Inzinerine Ekonomika-Engineering Economics, 25(3), 341-349. http://dx.doi.org/10.5755/j01.ee.25.3.6424

GRI. Reporting Principles and Standard Disclosures. Available from Internet: https://www.globalreporting. org/resourcelibrary/ GRIG4-Part1-Reporting-Principles-and-Standard-Disclosures.pdf

Grunert, J., Norden, L., \& M. Weber. (2005). The role of non-financial factors in internal credit ratings. Journal of Banking and Finance, 29(2), 509-531. http://dx.doi.org/10.1016/j.jbankfin.2004.05.017

Gyula Fulop, G., Bettina Hernadi, B., Jalali, M., Meidute-Kavaliauskiene, I., \& Ferreira, F. (2014). Developing of Sustainability Balanced Scorecard for the Chemical Industry: Preliminary Evidence from a Case Analysis. Inzinerine Ekonomika-Engineering Economics, 25(3), 341-349. http://dx.doi.org/10.5755/j01.ee.25.3.6424

IFAC (2012). Investor Demand for Environmental, Social and Governance Disclosures. Available from Internet: http://www.ifac.org/publi-cations-resources/investor-demand-environmental-social-and-governance-disclosures

Ittner, Ch. D., Larcker, D. F., \& Randall, T. (2003). Performance Implications of Strategic Performance Measurement in Financial Services Firms. Accounting, Organizations and Society, 28(7/8), 715-741. http//:dx.doi:10.1016/S03613682(03)00033-3

Kaplan, R. S., \& Norton, D. P. (2000). The Strategy Focussed Organisation. HBS Press, USA.

Kocmanova, A., \& Simberova, I. (2014). Determination of environmental, social and corporate governance indicators: framework in the measurement of sustainable performance. Journal of Business Economics and Management, 15(5), 1017-1033. http://doi.10.3846/16111699.2013.791637

Kristensen, K., \& Westlund. A. H. (2004). Accountable business performance measurement for sustainable business excellence. Performance Measurement and Business Results, 15(5-6), 719-734. http//:dx.doi:10.1080/14783360410001680116

Lacher, R. C. el at. (1995). A neural network for classifying the financial health of a firm. European Journal of Operational Research, 85(1), 53-65. http://dx.doi.org/10.1016/0377-2217(93)E0274-2

Lau, C. H., \& Sholihin, M. (2005) Financial and non-financial performance measures: How do they affect job satisfaction? The British Accounting Reviewer, 37, 389-413. http://dx.doi.org/10.1016/j.bar.2005.06.002

Nardo, M., Michaela Saisana, M., Andrea Saltelli, A., Tarantola, S., Hoffman, A., \& Giovannini, E. (2006). Handbook On Constructing Composite Indicators: Methodology and User Guide OECD, Statistics Working Paper.

Neumaierova, I., \& Neumaier, I. (2002). Vykonnost a trzni hodnota firmy. Praha, Grada.

Neumaierova, I., \& Neumaier, I. (2005). Index IN05. In Evropske financni systemy. (pp.143-148). Brno, Ceska republika: Masarykova univerzita.

OECD (2008). Handbook on Constructing Composite Indicators. Methodology and User Guide.

Ohlson, J. A. (1980). Financial Ratios and the Probabilistic Prediction of Bankruptcy. Journal of Accounting Research, 18(1), 109-131.

Pollak, H. (2003). How to restore the viability of declining companies. Praha, C. H. Beck.

Prieto, I. M., \& Revilla, E. (2006). Learning capability and business performance: a non-financial and financial assessment. Learning Organization, 13(2), 166-185. http://dx.doi.org/10.1108/09696470610645494

Russ, R. W., Achilles, W. W., \& Greenfield, A. C. (2009). The Altman z-score revisited. Journal of International Finance and Economics, 9(4), 59-73.

Rutkauskas, A. V., Stasytyte, V., \& Michnevic, E. (2014). Universally Sustainable Development Strategy for a Small Country: A Systemic Decision. Inzinerine Ekonomika-Engineering Economics, 25(5), 530-527. http://dx.doi.org/10.5755/j01.ee.25.5.3797 
Alena Kocmanova, Zaneta Simanaviciene, Marie Pavlakova Docekalova. Predictive Model for Measuring Sustainability ...

Schacht, K., Allen, J. C., \& Orsagh, M. (2009). The Corporate Governance of Listed Companies: A Manual for Investors. Available from Internet: http://www.cfapubs.org/doi/pdf/10.2469/ccb.v2009.n12.1

Soppe, A. (2009). Sustainable Finance as a Connection between CSR and SRI. Indian School of Business WP Indian Management Research Journal, 1(3), 1-23.

Wier, B., Hunton, J., \& Hassab E. H. R. (2007). Enterprise resource planning systems and non-financial performance incentives: The joint impact on corporate performance. International Journal of Accounting Information Systems, 8 , 165-190. http://dx. doi:10.1016/j.accinf.2007.05.001

Wu, Y., Gaunt, C., \& Gray, S. (2010). A comparison of alternative bankruptcy prediction models. Journal of Contemporary Accounting and Economics, 6(1), 34-45. http//:dx.doi:10.1016/j.jcae.2010.04.002

Xu, X., \& Wang, Y. (2009). Financial failure prediction using efficiency as a predictor. Expert Systems with Applications, 36, 366-373. http://dx. doi:10.1016/j.eswa.2007.09.040

Zmijewski, M. E. (1984). Methodological Issues Related to the Estimation of Financial Distress Prediction Models. Journal of Accounting Research, 22(4), 59-82. http://dx.doi.org/10.2307/2490859

The article has been reviewed.

Received in April, 2014; accepted in June, 2015. 